\title{
The left atrioventricular valve: The Achilles' heel of incomplete endocardial cushion defects
}

\author{
Meena Nathan, MD, MPH
}

From the Department of Cardiac Surgery, Boston Children's Hospital, Boston, Mass; and Department of Surgery, Harvard Medical School, Boston, Mass.

Disclosures: Author has nothing to disclose with regard to commercial support.

Received for publication Oct 31, 2018; accepted for publication Oct 31, 2018; available ahead of print Dec 8, 2018.

Address for reprints: Meena Nathan, MD, MPH, Department of Cardiac Surgery, Bader 273, 300 Longwood Ave, Boston, MA 02115 (E-mail: meena.nathan@ cardio.chboston.org).

J Thorac Cardiovasc Surg 2019;157:1130-1

$0022-5223 / \$ 36.00$

Copyright $(2) 2018$ by The American Association for Thoracic Surgery

https://doi.org/10.1016/j.jtcvs.2018.10.120

Incomplete forms of endocardial cushion defects include partial and transitional atrioventricular septal defects (AVSDs). These defects are characterized by 2 distinct atrioventricular valve orifices, unlike the complete atrioventricular canal defect that is characterized by a single/common atrioventricular valve orifice. ${ }^{1,2}$ In the current era, mortality after repair of partial and transitional AVSD is low $(0.3 \% \text { and } 0.9 \% \text {, respectively })^{2}$; however, despite modern advances in imaging and operative techniques, approximately $10 \%$ to $15 \%$ of these patients undergo unplanned reinterventions, particularly for left atrioventricular valve (LAVV) regurgitation or left ventricular outflow tract (LVOT) obstruction. ${ }^{1,3-10}$

In this issue of the Journal, Mery and colleagues ${ }^{11}$ report on outcomes of 265 patients with partial $(67 \%)$ or transitional AVSDs over a 22-year period. In one of the largest single-center reviews to date, they report low mortality (98\% survival at 10 years) and $15 \%$ and $19 \%$ reintervention rates at 5 years and 10 years, respectively. Although this was a retrospective review, they have reasonable follow-up having reached out to families and care providers for information. They have demonstrated that younger age (repair in the first year of life) and more complex anatomy are associated with reoperations, with LAVV reinterventions and LVOT reinterventions being the most common. As expected from a retrospective review, data on preoperative anatomy and physiology were based on reports and not confirmed by review of echocardiograms in a core laboratory; thus, the authors were unable to create predictive models for reinterventions.

There is conflicting information about the association between age of repair and interventions on the LAVV or LVOT. $^{3-7}$ In several studies, younger age is an important risk factor in reintervention. ${ }^{3-5}$ In contrast, the Pediatric Heart Network Investigators ${ }^{6,7}$ demonstrated a prevalence of moderate or greater LAVV regurgitation more common in children who were aged more than 4 years at partial/ transitional AVSD repair. Despite such conflicting data, it

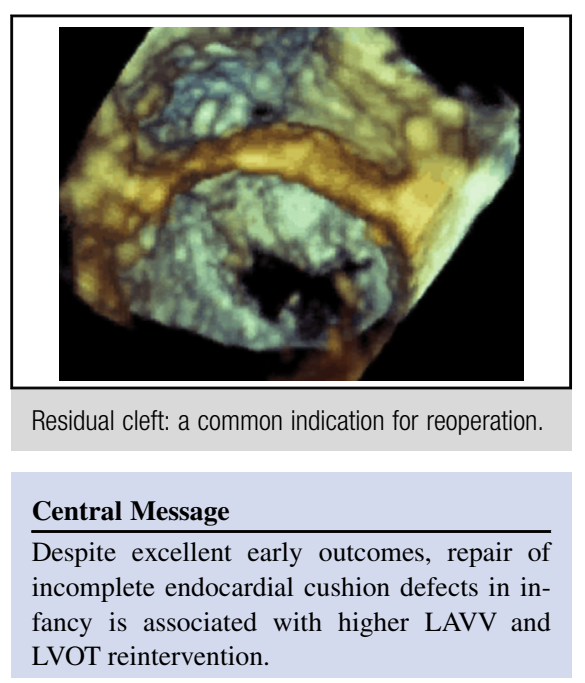

See Article page 1117.

makes intuitive sense that repair in infancy preselects a higher-risk cohort who require more urgent repair (of what is essentially an atrial level shunt and is usually well tolerated) and are more likely to have significant abnormalities not only of the LAVV but also of other left-sided structures. This increases their risk for reoperations on the LAVV or LVOT.

Not surprisingly, preoperative LAVV regurgitation was the single most important predictor for LAVV reinterventions in partial and transitional AVSD. ${ }^{4,5,8,9}$ As expected, severity of LAVV regurgitation at discharge predicted reintervention on the LAVV. ${ }^{10}$ The cause of LAVV regurgitation can be attributed to abnormal morphology of the LAVV encompassing abnormal leaflets, atypical clefts, and abnormal subvalvular apparatus that results in leaflet prolapse or restriction. At primary repair, every effort should be made to address these abnormalities and ensure adequate tension-free coaptation of the LAVV leaflets. ${ }^{12}$

As nicely illustrated by Mery and colleagues, ${ }^{11}$ younger age at repair is associated with higher rates of left-sided reintervention. Preoperative LAVV morphology and function remain the most important markers for successful repair and thus predictors of postdischarge reintervention on the atrioventricular valve.

\section{References}

1. Craig B. Atrioventricular septal defect: from fetus to adult. Heart. 2006;92 1879-85. 
2. Jacobs JP, Jacobs ML, Mavroudis C, Chai PJ, Tchervenkov CI, LacourGayet FG, et al. Atrioventricular septal defects: lessons learned about patterns of practice and outcomes from the congenital heart surgery database of the Society of Thoracic Surgeons. World J Pediatr Congenit Heart Surg. 2010;1:68-77.

3. Manning PB, Mayer JE, Sanders SP, Coleman EA, Jonas RA, Keane JF, et al. Unique features and prognosis of primum ASD presenting in the first year of life. Circulation. 1994;90(5 Pt 2):II30-5.

4. Najm HK, Williams WG, Chuaratanaphong S, Watzka SB, Coles JG, Freedom RM. Primum atrial septal defect in children: early results, risk factors, and freedom from reoperation. Ann Thorac Surg. 1998;66:829-35.

5. Buratto E, McCrossan B, Galati JC, Bullock A, Kelly A, d'Udekem Y, et al. Repair of partial atrioventricular septal defect: a 37-year experience. Eur J Cardiothorac Surg. 2015;47:796-802.

6. Minich LL, Atz AM, Colan SD, Sleeper LA, Mital S, Jaggers J, et al; Pediatric Heart Network Investigators. Partial and transitional atrioventricular septal defect outcomes. Ann Thorac Surg. 2010;89:530-6.

7. Kaza AK, Colan SD, Jaggers J, Lu M, Atz AM, Sleeper LA, et al; Pediatric Heart Network Investigators. Surgical interventions for atrioventricular septal defect subtypes: the pediatric heart network experience. Ann Thorac Surg. 2011;92: 1468-75.

8. Abbruzzese PA, Napoleone A, Bini RM, Annecchino FP, Merlo M, Parenzan L. Late left atrioventricular valve insufficiency after repair of partial atrioventricular septal defects: anatomical and surgical determinants. Ann Thorac Surg. 1990;49: $111-4$.

9. Murashita T, Kubota T, Oba J, Aoki T, Matano J, Yasuda K. Left atrioventricular valve regurgitation after repair of incomplete atrioventricular septal defect. Ann Thorac Surg. 2004;77:2157-62.

10. Tishler B, Gauvreau K, Colan SD, Del Nido P, Nathan M. Technical performance score predicts partial/transitional atrioventricular septal defect outcomes. Ann Thorac Surg. 2018;105:1461-8.

11. Mery CM, Zea-Vera R, Chacon-Portilo MA, Zhang W, Binder MS, Kyle WB, et al. Contemporary results after repair of partial and transitional atrioventricular septal defects. J Thorac Cardiovas Surg. 2019;157:1117-27.

12. Baird CW, Myers PO, Marx G, del Nido PJ. Mitral valve operations at a highvolume pediatric heart center: evolving techniques and improved survival with mitral valve repair versus replacement. Ann Pediatr Cardiol. 2012;5:13-20. 